\title{
IPTEK BAGI MASYARAKAT OPTIMALISASI KOMPETENSI DAN KINERJA GURU BK BERBASIS ICT DI SMP MAGELANG
}

\author{
Hijrah Eko Putro, Farida \\ Fakultas Keguruan dan Ilmu Pendidikan \\ Universitas Muhammadiyah Magelang \\ Jl. Tidar No. 21 Magelang 56126 \\ Email : hijrah.ummgl@gmail.com
}

\begin{abstract}
ABSTRAK
Pengabdian ini bertujuan untuk: (1) Meningkatkan kualitas dan kinerja di lingkungan sekolah; (2) Meningkatkan kreativitas dan keterampilan guru dalam melaksanakan layanan bimbingan dan konseling kepada siswa ; (3) Menambah inovasi dalam mengelola penggunaan dan publikasi materi ajar.

Pengabdian ini dilaksanakan di Laboratorium Internet Fakultas Ekonomi Universitas Muhammadiyah Magelang, pada 9 September 2016. Peserta pelatihan adalah guru BK SMP di Magelang. Dalam rangka mencapai tujuan yang telah disebutkan sebelumnya, maka ditempuh langkah-langkah sebagai berikut: (1) Menghubungi Kepala Sekolah dan Ketua Musyawarah Guru Bimbingan Konseling untuk mengetahui sejauh mana guru memanfaatkan ICT dalam melakanakan memberikan layanan bimbingan konseling kepada siswa dan mencari data perlu atau tidaknya diadakan pelatihan peningkatan kinerja guru BK berbasis ICT; (2) Menyelenggarakan program pengenalan dan pelatihan, yang meliputi tahap pengenalan, tahap pelatihan, dan tahap evaluasi hasil; (3) Tahap pengenalan dan pelatihan dilakukan secara kelompok.

Berdasarkan hasil pengabdian dapat disimpulkan: (1) Kegiatan ini dapat meningkatan pengetahuan dan keterampilan dalam penggunaan ICT. (2) Kegiatan ini mampu meningkatan pengetahuan dan keterampilan dalam memberikan layanan bimbingan dan konselingyang lebih inovatif dan bervariatif. (3) Kegiatan ini mampu menumbuhkan semangat dalam peningkatan kinerja secara mandiri dengan memanfaatkan teknologi berbasis ICT.
\end{abstract}

Kata kunci: Kompetensi, Kinerja, ICT

\section{ABSTRACT}

Hijrah Eko Putro, Farida. IPTEK FOR THE COMPETENCE AND PERFORMANCE OPTIMIZATION ICT BASED FOR BK TEACHERS in Magelang's Junior High school. Service reports, Magelang: Universitas Muhammadiyah Magelang, December 2016.

The aim of this devotion is to : (1) Improve quality and performance in the school environment, (2) Increase creativity and skills of teachers in implementing guidance and counseling services to students, (3) Adding innovations in managing the use and publication of teaching materials

This devotion was conducted in the Laboratory High School of Economics, University of Muhammadiyah Magelang, on September 9, 2016. The training participants are BK teachers from junior high school in Magelang. In order to achieve 
the objectives that have been mentioned before, taken steps as follows: (1) Call the Principal and Chairman of the Council of Master Counseling to determine the extent to which teachers utilize ICT in the exercise providing counseling to students and find data on the need of BK teacher performance enhancement training based on ICT; (2) Carrying out the introduction and training program, which includes the introduction phase, the training stage, and the stage of evaluation of results; (3) Phase introduction and training of a control group.

Based on the results of devotion can be concluded: (1) This activity can increase knowledge and skills in the use of ICT. (2) This activity is able to improve their knowledge and skills in providing guidance and counseling services more innovative and varied. (3) This activity is able to cultivate the spirit of self-improved performance by utilizing ICT-based technologies.

Keyword: Competency, Performance, ICT

\section{PENDAHULUAN}

Pendidikan adalah usaha sadar dan terencana untuk mewujudkan suasana belajar dan proses pembelajaran agar peserta didik secara aktif mengembangkan potensi dirinya untuk memiliki kekuatan spiritual keagamaan, pengendalian diri, kepribadian, kecerdasan, akhlak mulia, serta ketrampilan yang diperlukan dirinya, masyarakat, bangsa, dan negara. Pendidikan nasional bertujuan untuk meningkatkan kualitas manusia Indonesia yaitu manusia yang beriman dan bertaqwa terhadap Tuhan Yang Maha Esa, berbudi pekerti luhur, berkepribadian mandiri, maju, cerdas, kreatif, trampil, disiplin, beretos kerja, potensial, bertanggung jawab dan produktif sehat jasmani dan rohani. Pendidikan nasional juga menumbuhkan semangat kebangsaan dan kesetiakawanan sosial, serta berorientasi masa depan.

Sigelman \& Shaffer (dalam Yusuf, 2009: 55) mendefinisikan sekolah yang efektif adalah sekolah yang memajukan, meningkatkan, atau mengembangkan prestasi akademik, ketrampilan sosial, sopan santun, sikap positif terhadap belajar, rendahnya absen siswa, dan memberikan keterampilanketerampilan yang memungkinkan siswa dapat bekerja.

Pada dasarnya sekolah mempunyai peranan atau tanggung jawab penting dalam membantu para siswa mencapai tugas perkembangannya. Sehingga sekolah seyogianya dapat berupaya menciptakan iklim yang kondusif, atau kondisi yang dapat memfasilitasi siswa untuk mencapai tugas perkembangan sebagai seorangremaja. Dalam kenyataannya fenomena yang berkembang saat ini menunjukkan indikasi bahwa sekolah sebagai faktor penentu bagi perkembangan kepribadian anak dan membantu pencapaian tugas perkembangan siswa belum sepenuhnya mampu menjalankan perannya.

Bimbingan dan Konseling merupakan salah satu komponen dari pendidikan nasional, mengingat bahwa Bimbingan dan Konseling adalah merupakan suatu kegiatan bantuan dan tuntunan yang diberikan kepada individu pada umumnya, dan siswa pada khususnya di sekolah dalam rangka meningkatkan mutunya. Hal ini sangat relevan jika dilihat dari perumusan bahwa pendidikan itu merupakan usaha sadar yang bertujuan untuk mengembangkan kepribadian dan potensi-potensinya (bakat, minat, dan kemampuannya). Kepribadian menyangkut masalah perilaku atau sikap mental dan kemampuannya meliputi masalah akademik dan ketrampilan. Tingkat kepribadian dan kemampuan yang dimiliki oleh seseorang adalah merupakan suatu gambaran mutu dari orang yang bersangkutan. Pada masyarakat yang semakin maju, masalah penemuan identitas pada individu menjadi semakin rumit. Hal ini disebabkan oleh tuntutan masyarakat maju kepada anggota-anggotanya 
menjadi lebih berat. Persyaratan untuk dapat diterima menjadi anggota masyarakat bukan saja kematangan fisik, melainkan juga kematangan mental psikologis, kultural, vokasional, intelektual, dan religius. Kerumitan ini akan terus meningkat pada masyarakat yang sedang membangun, sebab perubahan cepat terjadi pada masyarakat yang sedang membangun, akan merupakan tantangan pula bagi individu atau siswa. Keadaan inilah yang menuntut secara umum tujuan penyelenggaraan bantuan pelayanan Bimbingan dan Konseling adalah berupaya membantu siswa menemukan pribadinya, dalam hal mengenal kekuatan dan kelemahan dirinya, serta menerima dirinya secara positif dan dinamis sebagai modal pengembangan diri lebih lanjut. Selain itu manusia sepanjang hidupnya selalu mengalami perkembangan. Perkembangan tersebut berlangsung dalam beberapa tahap yang saling berkaitan. Gangguan pada salah satu tahap dapat mengakibatkan terhambatnya perkembangan secara keseluruhan. Untuk mengidentifikasi masalah perkembangan, diperlukan pengukuran kuantitatif tentang tingkatperkembangan mulai dari tingkat sekolah dasar sampai dengan perguruan tinggi.

Berkembangnya ilmu pengetahuan dan teknologi merupakan perwujudan terjadinya perubahan ke arah positif budaya yang dimiliki oleh manusia. Hal ini didasari pada sebuah keyakinan bahwa setiap hasil dari daya yang dimiliki manusia baik cipta, rasa, karsa dan karya yang dikatakan sebagai sebuah budaya dalam wujud teknologi akan meningkatkan produktifitas kerja manusia. Dikatakan demikian karena teknologi tercipta sedianya akan mempermudah serta meningkatkan efektifitas kerja manusia, sehingga manusia menjadi lebih produktif dalam bekerja. Teknologi juga dapat dikatakan sebagai hasil budaya manusia karena merupakan hasil dari gagasan manusia yang akhirnya melahirkan sebuah karya dan dapat menunjang kehidupan manusia.

Salah satu bidang kehidupan manusia yang saat ini sedang giat dalam menempatkan teknologi sebagai bagian penting dari proses dan program kerjanya adalah bidang pendidikan. Pendidikan menjadi salah satu bidang yang mencoba meningkatkan peranan teknologi sebagai salah satu penunjang proses peningkatan efektivitas hasil kerja melalui optimalisasi serapan peserta didik terhadap materi pembelajaran dan pendidikan. Salah satunya diwujudkan dengan pemanfaatan media-media pembelajaran berbasis komputer yang diharapkan dapat menarik minat dan memotivasi peserta didik dalam pembelajaran. Seperti dengan mulai diterapkannnya pembelajaran berbasis multimedia, e-learning serta pemanfaatan beberapa aplikasi komputer dalam pembelajaran. Selain itu kini juga semakin marak situs-situs internet yang menyediakan berbagai materi pelajaran yang dapat diakses gratis maupun berbayar yang dapat menunjang ketercapaian target kompetensi dasar yang harus dikuasai oleh peserta didik/ siswa.

Bimbingan dan konseling sebagai bagian integral pendidikan juga tak luput dari sentuhan-sentuhan teknologi dalam pelaksanannya. Semakin ditegaskannya peranan bimbingan dan konseling dalam sistem pendidikan nasional melalui UU No. 20 Tahun 2003 tentang sistem pendidikan nasional serta penegasan profesi bimbingan dan konseling dalam tatanan pedidikan formal (Abkin, 2008) seharusnya menjadi rujukan utama para konselordalam mengoptimalkan peranan teknologi dalam setiap layanan yang diberikan, baik itu secara klasikal, kelompok maupun dengan format individual. Sehingga proses pelayanan bimbingan dan konseling yang diharapkan dapat memandirikan siswa dapat secara optimal tercapai melalui alat bantu maupun layanan-layanan yang berbasis penggunaan teknologi informasi.

Perkembangan software yang pesat dan beragam membuat guru-guru di sekolah khususnya guru-guru SMP di kota Magelang mengalami kesulitan dalam memahami software apakah yang paling tepat dimanfaatkan dalam pembelajaran, atau dalam kegiatan administrasi yang mendukung proses pembelajaran. Selama ini, 
berbagai pelatihan keterampilan komputer yang ditawarkan bagi guru dari pihak dinas pendidikan, kurang mengena sasaran disebabkan oleh alasan-alasan berikut: (1) tidak tersedianya waktu untuk memberi pelatihan guru di kota Magelang,(2) jarang diberikan pelatihan kepada gurugurukarena sedikitnya tenaga instruktur, (3)sarana dan prasana komputer yang belum tersedia cukup untuk mendukung pelatihan.

Di sisi lain, seiring dengan pesatnya perkembangan teknologi komputer, guru-guru BK di SMP Kota Magelang sangat dituntut untuk meningkatkan profesionalitasnya.

Sebagai peletak pendidikan bagi generasi muda di negeri ini, guru bimbingan dan konseling dituntut untuk memberikan pelayanan yang prima dan terukur baik kepada siswa maupun orang tua yang membutuhkan bimbingan terkait perkembangan anak. Guru BK SMP di Kota Magelang juga layak untuk mendapatkan perhatian dalam hal pembimbingan berbagai kompetensi yang meningkatkan keprofesionalan mereka dari pendidikan tinggi. Bagi guru bimbingan dan konseling, hal tersebut merupakan sebuah kendala yang mungkin cukup meresahkan, dikarenakan selama ini pelatihan komputer dan analisis instrumen yang ada kurang maksimal sehingga kepercayaan publik atau masyarakat bahkan siswa sendiri merasa peran guru BK di SMP di Kota Magelang kurang maksimal .

Sebagai salah satu lembaga pendidikan yang mendidik calon tenaga edukatif, Jurusan Bimbingan dan Konseling Fakultas Keguruan Ilmu Pendidikan Universitas Muhammadiyah Magelang perlu berperan serta dalam membantu guru, khususnya guru bimbingan dan konseling dalam menangani permasalahan keterbatasan ketrampilan komputer yang menunjang kegiatanpembelajaran.Oleh karena itu perlu diselenggarakan pelatihan yang berdasarkan kebutuhan guru-guru bimbingan dan konseling. Melalui kegiatan tersebut, diharapkan dapat meningkatkan profesionalisme guru BK SMP di Kota Magelang dalam melaksanakan proses belajar mengajar dan layanan kepada siswa yang akhirnya akan bermuara pada meningkatnya kualitas anak didik sebagai generasi penerus bangsa.

ICT (Information Comunication Technology) kini telah menjadi poin penting dalam program pengembangan pendidikan nasional. Dalam rencana strategis kementrian pendidikan nasional 2005 - 2009 juga telah dirumuskan bahwa pengembangan dan pemanfaatan ICT untuk mendukung peningkatan peran dan fungsi pelayanan pendidikan. Sistem yang dikembangkan diusahakan untuk dapat memenuhi dua hal, yaitu (a) kebutuhan manajemen atas sistem pendataan dan informasi yang akurat, mutakhir (up to date), dan mudah diakses; (b) kebutuhan masyarakat atas data dan informasi pelayanan pendidikan. Beberapa kegiatan yang sifatnya pengembangan dan pemanfaatan ICT, antara lain sebagai berikut (1) merancang dan mengimplementasikan sistem jaringan pendidikan nasional (Jardiknas), yang mencakup jaringan intranet dan internet, yang terhubung ke semua unit utama dan unit kerja Depdiknas di pusat, dinas pendidikan provinsi, dinas pendidikan kabupaten/kota, satuan pendidikan/sekolah, UPT pendidikan lainnya dengan pusat data dan aplikasi/IDC (Information Databse Center), (2) merancang dan membuat aplikasi pangkalan data (database) yang menyimpan dan pengolah data dan informasi sistem dan prosedur keuangan, sistem perencanaan dan sistem monitoring, sistem kepegawaian, sistem pengawasan internal, sistem aset, sistem nomor pokok sekolah nasional (NPSN), sistem nomor induk siswa nasional (NISN), sistem nomor induk mahasiswa, sistem nomor induk guru nasional (NIGN), sistem nomor induk dosen, dan konten-konten pembelajaran lainnya; (3) menyediakan dan meningkatkan pemanfaatan TV edukasi sebagai materi pengayaan dalam rangka menunjang peningkatan mutu pendidikan; dan (4) memfasilitasi pengumpulan/ pemanfaatan media massa guna peningkatan 
proses pembelajaran dan pengajaran. Selain itu juga akan dilakukan penataan sistem dan mekanisme inventarisasi dan dokumentasi sarana,prasarana dan aset pendidikan, termasuk pengelolaan dokumen dan arsip Depdiknas yang saat ini mengadapi kesulitan. Kegiatan ini dapat memanfaatkan peran TIK yang dapat mentransformasikan pendataan dan kearsipan konvensional ke sistem digital (Kemendiknas. 2005: 60).

Pemanfaataanteknologikomputerdalam pembelajarantampaknyasudah merupakan keharusan dan kebutuhan. Berbagai kemungkinan pemanfaatan komputer beserta berbagai programnya telah dikaji dan diekplorasi.Russeffendi (1999:420) mengemukakan beberapa alasan mengapa komputer diterapkan di sekolah, yaitu antara lain sebagai berikut: a).Peserta didik mempunyai sikap yang positif, b).Komputer dapat memberikan umpan balik secara langsung kepada peserta didik, c).Soal-soal dapat diselesaikan jauh lebih cepat.

Selain berperan langsung dalam proses pembelajaran,komputer memberikan dukungan yang tidakkalah pentingnya dalam kegiatan administrasi terkait proses pembelajaran. Kegiatan penyusunan rencana pembelajaran, pengolahan nilai dan penyimpanan dokumen lain menjadi hal yang sangat mudah dengan kehadiran komputer sebagai piranti bantu. Pekerjaan peng-administrasi-an yang dulu harus dikerjakanselama berhari-hari oleh guru, dapat diselesaikan dalam hitungan jamsaja. Sedemikian pentingnya peran komputer dalam kegiatan pembelajaran, sehingga gurusangat perluuntuk mempunyai penguasaan ketrampilan komputer yang cukup sehingga dapat meningkatkan kualitas pembelajaranyang dilaksanakannya.

\section{METODE RANCANGAN PENGABDIAN}

Untuk memudahkan monitoring, pembagian tugas dan tanggung jawab antara pengusul IbM dengan Mitra, rencana kegiatan IbM ini disajikan dalam gambar berikut.






\section{HASIL DAN PEMBAHASAN}

Pelaksanaan kegiatan PPM diawali dengan mengirimkan surat undangan kepada Kepala sekolah di beberapa sekolahyang tersebar di kota dan kabupaten Magelang dengan total sejumlah 10 sekolah dengan setiap sekolah diwakili oleh seorang guru BK. Disamping itu juga kami juga melibatkan mahasiswa sebagai pendamping Guru BK dari Sekolah yang tidak dilibatkan atau diberikan pelatihan Blogger, sehingga tetap ada kesinambungan dalam menyebarluaskan pentingnya Blogger bagi Guru BK, khususnya SMP.

Guru-guru yang telah mengirimkan angket kembali kepada tim pengabdi sekaligus mendaftar sebagai peserta pelatihan (ada 10 guru dan 6 mahasiswa).

Kegiatan pelatihan dilaksanakan selama1 hari, pada tanggal 9 September 2016. Bertempat di Laboratorium Pusat Komputer Fakultas Ekonomi Universitas Muhammadiyah Magelang, selama kurang lebih 8 jam, dari jam 08.00-16.00 WIB, dengan diikuti oleh 10 guru BK SMP di Kota dan kabupaten Magelang dan 6 Mahasiswa BK yang akan dijadikan pendamping di Sekolah pada tahap selanjutnya

Dalam pelaksanaan pelatihan, diadakan pengekplorasian fitur-fitur dalam software yang telah dikenal guru (antara lain software Blog dalam kelompok Microsoft Office) untuk mengakomodasi kebutuhan guru sesuai dengan kategori diatas.

Pada pelatihan komputer ini dipandu oleh tenaga instruktur komputer dari Fakultas Ekonomi. Sesi pertama, diawali dengan membagikan pretest kepada para peserta untuk mengetahui kemampuan awal pengoperasian microsoft office dan blog sehingga tim dapat menyesuaikan sesuai tingkat kemahiran dan kemampuan para peserta.
Tabel 4. Hasil Pretest Kegiatan Pelatihan

\section{Evaluasi Awal}

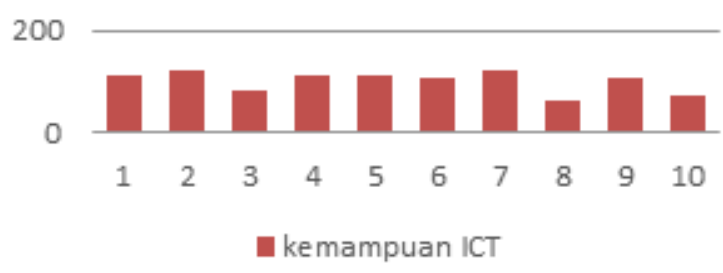

Berdasarkan data di atas, maka dapat disimpulkan bahwa persentase peserta yang terbiasa menggunakan komputer dalam menunjang kegiatan pembelajaran dikategorikan cukup meskipun belum terlalu tinggi. Namun sebagian besar peserta memiliki motivasi yang sangat tinggi untuk belajar dan dapat menggunakan aplikasi komputer sebagai alat bantu maupun inovasi dalam proses belajar mengajar.

Setelah pengisian angket selesai, kegiatan dilanjutkan dengan memberikan pemahaman awal tentang materi yang akan disampaikan. Hal ini dilakukan untuk menambah wawasan guru terkait aplikasi apa yang sedang up to date saat ini dan memberikan motivasi kepada guru agar mau belajar dan menerapkan aplikasi ini.

Pada sesi pertama ini peserta dilatih dalam memaksimalkan pemanfaatan Microsoft Office khususnya word dan excel sebagaisarana untuk mengaplikasikan blog. Peserta pelatihan diminta membut administrasi data terkait yang itu digunakan sebagai sarana pendukung dalam mengaplikasikan blog. Sesi pertama dilaksanakan sekitar 2 jam dengan hasil yang baik setiap peserta mampu membuat administrasi data dengan bantuan modul pelatihan microsoft word excel.

Sesikedua, pelatihan diisi dengan materi optimalisasi fitur Microsoft Word untuk pendukung proses pemberian layanan. Dalam sesi ini, peserta pelatihan diajak untuk mengeksplorasi fasilitas menu mailmerge dalamMicrosoftWord. Mailmerge adalah fasilitas yang sangat bermanfaat untuk pembuatan surat, dokumen atau laporan secara massal. Fasilitas ini sangat membantu 
guru dalam kegiatan administrasi sekolah, misalnya untuk membuat surat undangan, laporan kemajuan siswa,dan sebagainya.

Masih berkaitan dengan eksplorasi MicrosoftWord, pengolahan dokumen yang berupa pembuatan daftar isi otomatis merupakan materi pada sesi berikutnya. Materi ini cukup menarik perhatian peserta pelatihan, karena peserta belummengenal fasilitas tersebutsebelumnya, disebabkan ketidaktahuan mereka. Materi pendalaman Microsoft Word memakan waktu dari awal pembukaan pelatihan hingga waktu istirahat.

Setelah istirahat, sesi ketiga/terakhir, disampaikan materi pengolahan data administrasi menggunakan Microsoft Excel. Peserta dikenalkan dengan cara memasukkan data nilai siswa, menjumlah,mencari ratarata, mencari nilai tertinggi/ terendah, membuat ranking nilai dan menggunakan fungsi referensi vlookup dan hlookup.

Selanjutnya di sesi terakhir instruktur menyampaikan materi terkait blog yang merupakan materi inti yang diberikan kepada peserta pelatihan.

Dalam setiap sesi, saat satu anggota bertugas menyampaikan materi, yang lain mendampingi peserta pelatihan dan memberikan penjelasan per individu sehingga kesulitan yang dihadapi oleh peserta dapat segera diatasi, sehingga waktu yang digunakan menjadi lebih optimal.

Pada akhir sesi ketiga, tim pengabdi membagikan angket evaluasi/ posttest pelaksanaan. Angket berupa pertanyaan terbuka untuk mengetahui pendapat peserta tentang pelaksaan kegiatan guna perbaikan kegiatansejenis di masa mendatang. Adapun hasil Hasil Evaluasi Post test terhadap kegiatan pelatihan disajikan dalam Tabel.

\section{Evaluasi Akhir}

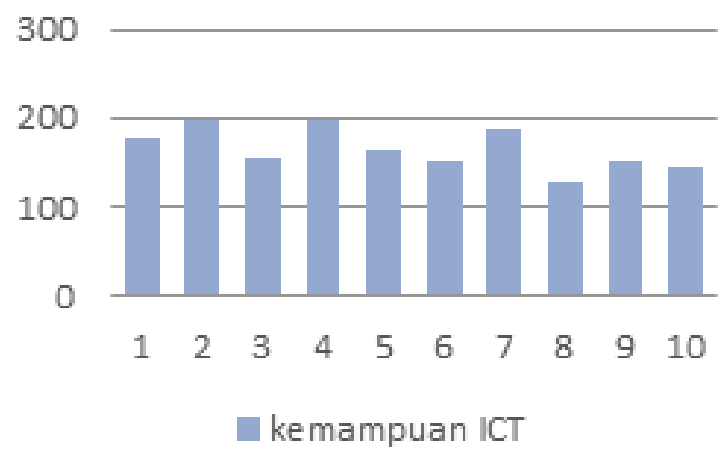

Kegiatan evaluasi dilaksanakan dalam rangka mengetahui tingkat pemahaman peserta terhadap kegiatan yang sudah dilaksanakan. Kegiatan ini dilaksanakn dengan metode angket. Peserta diminta mengisi beberapa angket yang sudah disediakan. Kemudian peserta juga diminta memberikan masukan/saran dari rangkaian kegiatan yang sudah dilaksanakan.

Ketercapaian pelatihan ini diukur dengan keberhasilan peserta dalam membuat blog dan mengaplikasikannya yang telah terkomputerisasi beserta pengembangannya. Dalam hal ini, peserta pelatihan telah mampu membuat blog dengan program blogger. Peserta diberikan soal pretest, untuk mengetahui kemampuan sebelum pelatihan, setiap peserta wajib mengikuti evaluasi melalui ujian praktik atau posttest setelah pelatihan berakhir.

Secara garis besar, kegiatan ini menunjukkan bahwa target luaran telah terpenuhi. Peserta mampu meningkatkan penguasaan penggunaan komputer untuk mendukung proses pemberian yang terkait penguasaan keterampilan komputer yang dibutuhkan dalam pengaplikasian progam software.

Kegiataninidapatdisempurnakandengan pemberian pelatihan dan pengembangan lebih lanjut, terutama bagi guru BK sehingga mereka mempunyai kompetensi dan kinerja yang lebih optimal. 


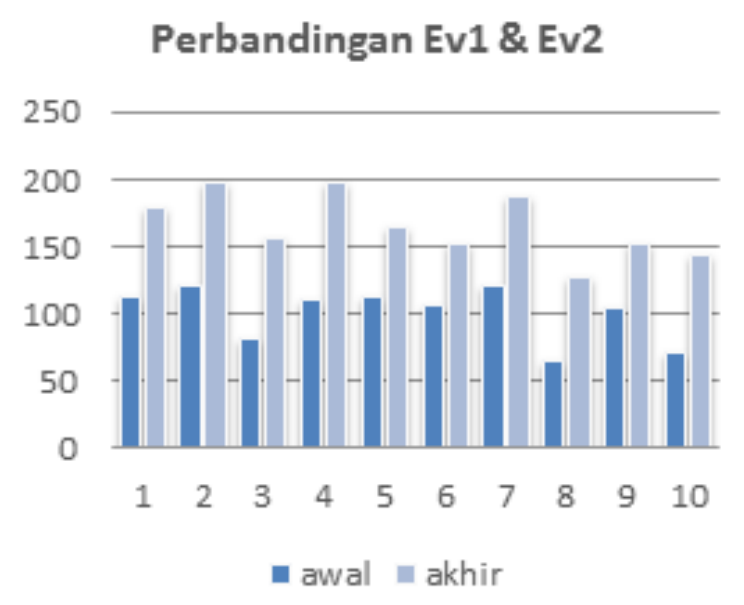

Berdasarkan data angket pascakegiatan yang diisi 10 peserta menunjukkan keterserapan akhir tentang penggunaan ICT dalam peningkatan kinerja guru BK. Ratarata persentase keterserapan akhir sebesar $40 \%$ menunjukkan secara rata-rata meningkat apabila dibandingkan dengan katerserapan awal peserta. Ini berarti bahwa pelatihan ini cukup efektif untuk meningkatkan kinerja dan kompetensi guru BK dalam penggunaan ICT dalam proses pemberian layanan.

Dari uraian di atas dapat disimpulkan bahwa kegiatan pelatihan yang telah dilaksanakan berhasil memenuhi tujuannya. Tidak ada hambatan yang berarti dalam pelaksanaan kegiatan, baik dalam persiapan maupun dalam pelaksanaan kegiatan pelatihan.

\section{KESIMPULAN}

Berdasarkan refleksi hasil kegiatan yang telah dilakukan, maka dapatditarik beberapakesimpulansebagaiberikut:

Kegiatan PPM ini dapat meningkatkan ketrampilan guru, khususnya guru BK SMP dalam penguasaan menggunakan komputer untuk mendukung proses pemberian yang terkait Penguasaan keterampilan komputer yang dibutuhkan dalam pengaplikasian ICT.

GuruBK dapat mengoptimalkan ICT untuk meningkatkanmutu pelayanan kep ada siswa dan mempermudah pengelolaan administrasi dengan mengeksplorasi software yang belum banyak digunakan.

Motivasi peserta pelatihan untuk memanfaatkan perangkat lunak bantu untuk meningkatkan mutu pemberian layanan dan mempermudah administrasi dapat ditingkatkan dengan caramenunjukkanberbagaifitur yangada dan kemudahannya dalam pengolahan data dan dokumen dalam blog.

\section{DAFTAR PUSTAKA}

Arsyad, Azhar. 2001. Media Pengajaran. Jakarta: PT Raja Grafindo

Ross, M.S., Kemp, J.E. 2004. Designing Effective Instruction $\left(4^{\text {th }}\right.$ Edition). USA: John Wiley \& Son Inc.

Moh.Uzer Usman. 2002. Menjadi Guru Profesional. Bandung : PT Remaja Rosdakarya.

Morrison,R.G., Ross,M.S., Kemp, J.E. 2004. Designing Effective Instruction (4 ${ }^{\text {th }}$ Edition). USA: John Wiley \& Sons, Inc.

Newby, T.J., Stepich, D.A., Lehman, J.D., Russell, J.D. (2000). Instructional Technology for Teaching and Learning. Designing Instruction, Integrating Computers, and Using Media (second edition). New Jersey: Prentice-Hall,Inc.

Slameto. (1995). Belajar dan Faktor-faktor yang Mempengaruhinya. Jakarta : PT Rineka Cipta.

Yusuf, Syamsu. 2009. Psikologi Perkembangan Anak dan Remaja. Bandung: Remaja Rosdakarya 